\title{
Factor Adjustment Spikes and Interrelation: an empirical Investigation
}

Citation for published version (APA):

Letterie, W. A., Pfann, G. A., \& Polder, J. M. (2004). Factor Adjustment Spikes and Interrelation: an empirical Investigation. Economics Letters, 85, 145-150. https://doi.org/10.1016/j.econlet.2004.03.017

Document status and date:

Published: 01/01/2004

DOI:

10.1016/j.econlet.2004.03.017

Document Version:

Publisher's PDF, also known as Version of record

\section{Please check the document version of this publication:}

- A submitted manuscript is the version of the article upon submission and before peer-review. There can be important differences between the submitted version and the official published version of record.

People interested in the research are advised to contact the author for the final version of the publication, or visit the DOI to the publisher's website.

- The final author version and the galley proof are versions of the publication after peer review.

- The final published version features the final layout of the paper including the volume, issue and page numbers.

Link to publication

\footnotetext{
General rights rights.

- You may freely distribute the URL identifying the publication in the public portal. please follow below link for the End User Agreement:

www.umlib.nl/taverne-license

Take down policy

If you believe that this document breaches copyright please contact us at:

repository@maastrichtuniversity.nl

providing details and we will investigate your claim.
}

Copyright and moral rights for the publications made accessible in the public portal are retained by the authors and/or other copyright owners and it is a condition of accessing publications that users recognise and abide by the legal requirements associated with these

- Users may download and print one copy of any publication from the public portal for the purpose of private study or research.

- You may not further distribute the material or use it for any profit-making activity or commercial gain

If the publication is distributed under the terms of Article $25 \mathrm{fa}$ of the Dutch Copyright Act, indicated by the "Taverne" license above, 


\title{
Factor adjustment spikes and interrelation: an empirical investigation
}

\author{
Wilko A. Letterie ${ }^{\mathrm{a}}$, Gerard A. Pfann ${ }^{\mathrm{b}}$, J. Michael Polder ${ }^{\mathrm{c}, *}$ \\ ${ }^{a}$ Business Investment Research Center, Department of Organization and Strategy, Maastricht University, The Netherlands \\ ${ }^{\mathrm{b}}$ Business Investment Research Center, CEPR, Maastricht University, The Netherlands \\ ${ }^{\mathrm{c}}$ Department of Quantitative Economics, Business Investment Research Center, Maastricht University, P.O. Box 616, \\ 6200 MD Maastricht, The Netherlands
}

Received 15 July 2003; received in revised form 4 January 2004; accepted 9 March 2004

Available online 2 July 2004

\begin{abstract}
We take a descriptive look at interrelated factor demand starting from the observation that adjustment of capital and labor is lumpy. We find that the adjustment dynamics of an input factor are affected by large adjustments in the other.

(C) 2004 Elsevier B.V. All rights reserved.
\end{abstract}

Keywords: Investment; Labor demand; Interrelated factor demand; Non-convex adjustment costs

JEL classification: D21; D92; J23

\section{Introduction}

Empirical research over the last decade has documented that factor demand is 'lumpy' at the microlevel, in the sense that firms tend to concentrate adjustments in short periods of time, see e.g. Doms and Dunne (1998) for investment, and Hamermesh (1989) for labor adjustment. Structural models that stress the importance of non-convex adjustment costs and irreversibilities in this context have been proposed by e.g. Abel and Eberly (1994).

Empirical work along these lines has focused on models with a single quasi-fixed input factor, see e.g. Barnett and Sakellaris (1998). Recently, some theoretical studies have investigated interrelated factor demand with multiple quasi-fixed input factors where one or more factors are subject to non-

* Corresponding author. Tel.: +31-433-88-3673; fax: +31-433-88-4856.

E-mail address: m.polder@ke.unimaas.nl (J.M. Polder). 
convexities or irreversibility (e.g. Dixit, 1997). As a first step towards a more structural empirical analysis, this paper provides a descriptive investigation into the relevance of interrelation starting from the observation that adjustment of capital and labor is lumpy. We find that adjustment lumps for one factor affect the dynamics of the other.

\section{Data and descriptive statistics}

We analyze annual data collected by Statistics Netherlands (CBS) concerning product plants in the Dutch manufacturing sector. For convenience, we will refer to all units as firms. The data is available for firms with more than 20 employees, and only positive investments are observed (more details on the definition and construction of the variables are given in Letterie and Pfann, 2003). The entry and exit of firms is likely to be due to major investment and disinvestment decisions, which do not reflect the regular adjustment pattern of a firm. Therefore we prefer to analyze a balanced set of data, although this may bias the information towards larger and successful establishments. To avoid contamination of the results by exceptional outliers, we also exclude firms for which the investment ratio exceeds one for one or more periods. We end up with 659 firms for which all information is available for the period 1978 to 1992. The first 5 years of the sample are used to construct a capital stock measure according to a perpetual inventory method.

To determine whether firms conduct major investment efforts during a particular year we employ the so-called relative and absolute spike definitions. The former classifies an observation as a spike if the investment rate exceeds the median investment rate over a certain period by $75 \%$ (Power (1998)); with the latter definition an observation is called a spike if the investment rate exceeds $20 \%$ (e.g. Cooper et al., 1999). Following Sakellaris (2001), we categorize an observation as a positive employment spike if the adjustment rate of employment exceeds $10 \%$, and as a negative employment spike if it is smaller than $-10 \%$.

Table 1 displays some descriptive statistics with respect to the adjustment of employment and capital. The investment rate is about $10 \%$ on average, but with a median of about $6 \%$ it is positively skewed. Average labor adjustment is around zero with only a slight positive skewness. About $12 \%$ are absolute investment spikes, while the relative spike definition gives as much as $22 \%$. This difference is striking. The percentage zero-adjustment is considerably higher for labor, although this observation is somewhat biased by the fact that we only observe net labour adjustment.

Conditioning on whether a spike occurs in the other production factor or not, large differences are observed. ${ }^{1}$ If there is an investment spike labor adjustment increases to $5 \%$ on average. In addition, more positive employment spikes occur if there is an investment spike, and there occur less negative employment spikes. There is also some mild evidence that there is less zero adjustment of labor in times of an investment spike. In times of a positive employment spike the average investment rate is considerably higher than when there is no employment spike. It is considerably lower if there is a negative employment spike. Also, there occur more investment spikes if there is a positive employment spike, and less if there is a negative employment spike. Finally, there is more zero investment in times of a negative employment spike.

\footnotetext{
1 The standard errors of the statistics (not reported to save space) show that most differences are highly significant.
} 
Table 1

Descriptive statistics

\begin{tabular}{|c|c|c|c|c|c|}
\hline & Total & $\mathrm{ABS}=0$ & $\mathrm{ABS}=1$ & $\mathrm{REL}=0$ & $\mathrm{REL}=1$ \\
\hline & Mean (med.) & Mean (med.) & Mean (med.) & Mean (med.) & Mean (med.) \\
\hline$(\Delta L / L)_{t}$ & $0.015(0)$ & $0.010(0)$ & $0.050(0.037)$ & $0.010(0)$ & $0.034(0.023)$ \\
\hline POS & $0.147(0)$ & $0.133(0)$ & $0.247(0)$ & $0.132(0)$ & $0.196(0)$ \\
\hline NEG & $0.096(0)$ & $0.100(0)$ & 0.063 (1) & $0.103(0)$ & $0.073(0)$ \\
\hline \multirow[t]{3}{*}{$D\left[\Delta L_{t}=0\right]$} & $0.137(0)$ & $0.141(0)$ & $0.106(0)$ & $0.139(0)$ & $0.128(0)$ \\
\hline & Total & $\mathrm{POS}=0$ & $\mathrm{POS}=1$ & $\mathrm{NEG}=0$ & $\mathrm{NEG}=1$ \\
\hline & Mean (med.) & Mean (med.) & Mean (med.) & Mean (med.) & Mean (med.) \\
\hline$(I / K)_{t}$ & $0.098(0.063)$ & $0.092(0.060)$ & $0.135(0.093)$ & $0.101(0.067)$ & $0.070(0.034)$ \\
\hline $\mathrm{ABS}$ & $0.124(0)$ & $0.109(0)$ & $0.209(0)$ & $0.128(0)$ & $0.082(0)$ \\
\hline REL & $0.228(0)$ & $0.215(0)$ & $0.305(1)$ & $0.233(0)$ & $0.174(0)$ \\
\hline$D\left[I_{t}=0\right]$ & $0.042(0)$ & $0.042(0)$ & $0.038(0)$ & $0.038(0)$ & $0.073(0)$ \\
\hline
\end{tabular}

Explanation of abbreviations: $\mathrm{POS}=$ positive employment spike; $\mathrm{NEG}=$ negative employment spike; ABS=absolute investment spike; REL $=$ relative employment spike; $D[\cdot]=1$ if $[\cdot]$ is true, zero otherwise.

These statistics show that there is a relation between the adjustment of an input factor and whether or not there is a spike in the other factor. Another thing worth mentioning, however, is the heterogeneity in response. For example, while average employment adjustment increases considerably if there is an investment spike, in $7 \%$ of the observations it is coupled with a negative employment spike. Also, capital and labor do not necessarily 'spike together'. Only about $20 \%$ of the positive employment spikes occur in the same period as an investment spike, for example.

\section{Lumpiness and interrelation}

The purpose of this section is to investigate how firms adjust the employment level (respectively, capital stock) in periods of investment (respectively, labor adjustment) spikes, and in periods before and after such spikes. ${ }^{2}$ This does not only offer insight into whether there is above average adjustment in times of adjustment spikes, but also gives an idea about the dynamics of the interrelation between investment and employment decisions.

Analogous to Power's (1998) investment age variables, we use indicator variables to represent the timing of lumpy investment episodes. We define four indicator variables as $1_{k} \equiv 1$ [investment period $=k]$, where $k=\{$ next, current, previous, between $\}$. For instance $1_{\text {current }} \equiv 1$ [investment period $=$ current] equals 1 if the firm has an investment spike in the current period, and zero otherwise. The variable 1 [investment period = next (previous)] equals 1 if the concerning firm has an investment spike in the next (previous) period, where it does not have one in the current or previous (next) period. ${ }^{3}$

\footnotetext{
2 See Sakellaris (2001) for a related study.

3 A category 'between' is introduced to take account of those observations for which a firm has a spike in the previous as well as in the next period, while in the current period no spike occurs. Because this is a side category with sometimes very few observations, we omit it from the discussion.
} 
To investigate the relation between the timing of a large investment and labor adjustment we consider the estimating equation

$$
(\Delta L / L)_{i t}=\alpha_{i}+\lambda_{t}+\sum_{k} \beta_{k}\left(1_{k}\right)_{i t}+\varepsilon_{i t}
$$

where $\lambda_{t}$ is a year dummy, and $\varepsilon_{i t}$ is an idiosyncratic disturbance. The fixed effect $\alpha_{i}$ accounts for a firm specific average adjustment rate and makes the results robust to any omitted time-invariant variables. Eq. (1) is first-differenced and estimated by least squares. The estimation results are presented in Table 2.

The results indicate that firms hire significantly more people in periods close to investment spikes and the period of the spike itself. This suggests that the employment and the investment decision are significantly interrelated. The fact that investment spikes tend to have a positive effect on employment changes supports the view that labor and capital are complementary inputs. Also, the apparent high labor demand in periods right before or after an investment spike indicate that there is a dynamic element in the relation between labor and capital. The fact that firms hire employees in advance of an investment lump may indicate that employees need to be trained. As soon as the new capital comes in these employees can start working with it, or manage the employees that are hired in the same period as the spike. On the other hand, the excess hiring in the period after a spike may reflect labor market scarcities, or a learning effect by the firm that it needs more labor to get the work done. The results do not depend on the definition of the investment spike and support those of Sakellaris (2001).

It is also interesting to look at the relation between the investment rate and employment spikes. To investigate this we estimate

$$
(I / K)_{i t}=\alpha_{i}+\lambda_{t}+\sum_{k} \beta_{k}\left(1_{k}\right)_{i t}+\varepsilon_{i t}
$$

where the indicator variables $1_{k}$ now reflect whether there was an employment spike in period $k$. The estimation results are reported in Table 3 . It can be seen that there is significantly more (less) investment in periods of a large positive (negative) employment change. In addition, there is some evidence that there is more (less) investment in the period after an employment spike.

The results in Tables 2 and 3 should be put in the light of the heterogeneity found in the previous section. For example, from Table 2 it can be seen that firms hire about $3 \%$ more people in periods of an investment spike on average. At the same time, however, as became clear from Table 1, some firms do

Table 2

Effect of investment spikes on employment changes

\begin{tabular}{lll}
\hline & Absolute & Relative \\
\hline Next & $0.017(0.007)^{*}$ & $0.011(0.054)^{*}$ \\
Current & $0.030(0.006)^{* *}$ & $0.030(0.005)^{* *}$ \\
Previous & $0.015(0.007)^{*}$ & $0.011(0.055)^{*}$ \\
Between & $0.028(0.015)$ & $0.033(0.010)^{* *}$ \\
\hline
\end{tabular}

Standard errors are reported in parentheses.

* Significant at 5\% level.

** Significant at $1 \%$ level. 
Table 3

Effect of employment spikes on investment

\begin{tabular}{llr}
\hline & Positive & Negative \\
\hline Next & $0.007(0.055)$ & $-0.011(0.007)$ \\
Current & $0.031(0.005)^{* *}$ & $-0.027(0.006)^{* *}$ \\
Previous & $0.008(0.005)$ & $-0.013(0.006)^{*}$ \\
Between & $0.024(0.011)^{*}$ & $-0.047(0.011)^{* *}$ \\
\hline
\end{tabular}

Standard errors are reported in parentheses.

* Significant at 5\% level.

** Significant at $1 \%$ level.

not adjust employment when there is an investment spike or even exhibit a negative employment spike. A more structural analysis should be able to distinguish between those cases.

\section{Concluding remarks}

In this paper, we investigate the dynamic interrelation between factor demand in the context of lumpy adjustment. With plant-level data for the Dutch manufacturing sector, we find that the dynamics of employment are significantly related to large investments. Also, investment is related to large employment changes. Although our results do not necessarily have a causal or structural interpretation, they indicate that in modeling the demand for production factors the interrelation among them should be taken into account. While the traditional literature has investigated this in linear-quadratic models (Nadiri and Rosen, 1969), no empirical research has been carried out with multiple quasi-fixed input factors where one or more factors are subject to non-convexities. This should prove to be a worthwhile direction for future research.

\section{Acknowledgements}

This paper has benefited from helpful comments by Eric Bartelsman, Sher Verick, participants at the NAKE-day 2002, at the conference 'Firms' dynamic adjustment with nonconvexities and irreversibility at the University of Bergamo, and in the Q-seminar series at Maastricht University. All errors are our own. The authors acknowledge the PIONIER program (grant number 400-10-041) of the Netherlands Foundation for Scientific Research (NWO) and Statistics Netherlands for financial support. The empirical part of this paper was carried out at the Center of Research of Economic Micro Data (CEREM) at Statistics Netherlands. We thank our contacts there for their kind cooperation. The views expressed in this paper are those of the authors and do not necessarily reflect the policies of Statistics Netherlands.

\section{References}

Abel, A., Eberly, J., 1994. A unified model of investment under uncertainty. The American Economic Review 84, $1369-1384$. Barnett, S., Sakellaris, P., 1998. Nonlinear response of firm investment to Q: testing a model of convex and non-convex adjustment costs. Journal of Monetary Economics 42 (2), 261-288. 
Cooper, R., Haltiwanger, J., Power, L., 1999. Machine replacement and the business cycle: lumps and bumps. The American Economic Review 89 (4), 921-946.

Dixit, A., 1997. Investment dynamics in the short run and long run. Oxford Economic Papers 49, 1-20.

Doms, M., Dunne, T., 1998. Capital adjustment patterns in manufacturing. Review of Economic Dynamics 1, $409-429$.

Hamermesh, D., 1989. Labor demand and the structure of adjustment costs. The American Economic Review 79 (4), $674-689$. Letterie, W., Pfann, G., 2003. On the identification of non-linearity in equipment investment expenditures. Working paper. Nadiri, M., Rosen, S., 1969. Interrelated factor demand functions. The American Economic Review 59, $457-471$.

Power, L., 1998. The missing link: technology, investment, and productivity. Review of Economics and Statistics 80, $300-313$. Sakellaris, P., 2001. Patterns of plant adjustment. Working paper. 